\title{
突合せ溶接時の溶接高温割れ防止技術に関する検討*
}

\author{
前田 新太郎 ${ }^{* *}$, 柴原 正和 ${ }^{* * *}$, 生島 一樹 ${ }^{* * *}$, 三輪 剛士 ${ }^{* * * *}$, 山崎 圭 ${ }^{* * * *}$, \\ 西原 健作 ${ }^{* * * * *}$, 武田 裕之 ${ }^{* * * * * *}$, 麻 寧緒******
}

\section{Study on Prevention Method of Hot Cracking Under Butt Welding*}

\author{
by MAEDA Shintaro ${ }^{* *}$, SHIBAHARA Masakazu ${ }^{* * *}$, IKUSHIMA Kazuki $^{* * *}$, MIWA Tsuyoshi ${ }^{* * * *}$, YAMAZAKI Kei $^{* * * *}$, \\ NISHIHARA Kensaku ${ }^{* * * * *}$, TAKEDA Hiroyuki ${ }^{* * * * * *}$ and MA Ninshu ${ }^{* * * * * * *}$
}

\begin{abstract}
For the automation of butt welding, it has been considered to introduce tack welds instead of out-of-plane restraint jigs to perform welding with large heat input. However, the occurrence of hot cracking has been a significant issue in large heat input welding. In the previous report, the authors have developed a prediction method of hot cracking that can investigate the influence of not only the high temperature strain generated in the weld metal but also the phenomena related to solidification such as solidification shrinkage, latent heat of solidification and crystals growth direction. In this study, the conditions for prevention of hot cracking were investigated by numerical analysis and experiments through controlling the temperature gradient at solidification temperature using a trailing torch in tandem welding. As a result, it was confirmed that the large strain existing position predicted using proposed hot cracking analysis has a good agreement with the cracking position observed experimentally in tandem butt weld. It was also found that with increasing the electrode distance, both the columnar crystals associate angle became larger and the local strain became smaller. It can be concluded that the hot cracking can be successfully prevented in the practical experiments using the proposed large electrode distance.
\end{abstract}

Key Words: Hot cracking, Prevention of hot cracking, Thermal elastic plastic analysis, Crystals growth direction, Solidification shrinkage, Brittleness Temperature Range

\section{1. 緒言}

近年，輸送コストの削減を目的とした船舶の大型化に伴 う溶接施工数の増大と溶接作業員の確保が困難な状況など により，造船業において溶接施工の自動化が試みられてい る ${ }^{1)}$. 自動溶接においては, 作動性の観点から面外拘束板の 面内仮付けへの変更が求められる。 その際には, 溶接品質 の点から面内仮付けを再溶融することが必要となり，入熱 量の大きな溶接が求められる. しかしながら, 大入熱溶接 時には，溶接高温割れの発生が懸念される ${ }^{2)}$. 溶接高温割れ は, 溶接金属が㠜固する際の融点直下の温度域に扔いて, 大きな引張りひずみが作用した際に生じる溶接欠降-8) であ り，溶接部の健全性を著しく低下させる恐れがある，その ため, 溶接高温割れ発生の可能性が高い溶接部には溶接後 に非破壊検查が行われ，割れが確認された場合には補修溶

\footnotetext{
*受付日 2021年9月7日 受理日 2021年11月24日

**学生員 大阪大学大学院 Student member, Graduate School of Engineering, Osaka Univ.

***正 員 大阪府立大学大学院 Member, Graduate School of Engineering, Osaka Prefecture Univ.

****正 員 株式会社神戸製鋼所 Member, Kobe Steel, Ltd.

***** $\quad コ ヘ ゙ ル コ$ 溶接テクノ株式会社 Kobelco Welding TechnoSolutions Co., Ltd.

******正 員 コベルコ溶接テクノ株式会社 Member, Kobelco Welding TechnoSolutions Co., Ltd.

*******正 員 大阪大学接合科学研究所 Member, Joining and Welding Research Institute, Osaka Univ.
}

接が施されるなど，製造コスト増大の一因となっている. このことから, 溶接高温割れを防止することは重要な課題 である.

溶接高温割れにおける引張りひずみの発生要因は大きく 分けて二つあり, 一つは溶融金属自体の凝固に伴う凝固収 縮であり, もう一つは溶融金属周辺の拘束や変形である. つまり, 高温域で受けたひずみ量が溶接高温割れの発生を 評価する上で重要であり，そのひずみ量を低減できれば, 溶接高温割れが防止できると考えられる.

溶接高温割れを防止する方法として, Branza らは耐熱鋳 鉄の補修溶接時に，母材を予熱することおよび開先表面に ニッケルをバタリングすることで割れ発生が低減できるこ とを実験的に確認している9 . Leeらは，拘束緩和式U型高 温割れ試験において，溶接と同時に水冷を行うことで，割 れが発生しないことを確認している ${ }^{10)}$. しかしながら, 船舶 外板のような数十メートルを超える部材を予熱することや 溶接直後の溶接部を水冷することは現実的ではないと考え られる。また Schaeferらは，レーザ溶接時のレーザの出力 条件を変化させることで, 溶接速度ごとに割れ発生を大幅 に低減できる周波数があることを示した ${ }^{11)}$. Zhang らは, レー ザスポット溶接時の溶込み形状を変化させ, 溶込み形状の アスペクト比を制御することで，割れを防止できることを 確認している ${ }^{12)}$. また, Oshita らは，低炭素鋼の突合せ溶接 において，柱状晶どうしの会合角度が割れ発生に大きく影 
響することを実験的に確認している ${ }^{13)}$.このように，溶融部 の形状を変化させ，結晶の成長方向を制御することで溶接 高温割れを防止できると考えられる。しかしながら，溶达 み形状や結晶成長方向が溶接部のひずみに及ぼす影響につ いて実験的に数多く検討することは高コストであり，その 検討には，最低限必要な実験に加え溶接に伴う部材の変形 および溶融金属部の凝固に伴うひずみを詳細に検討可能な 数值シミュレーションが有効と考えられる。

溶接高温割れの数值シミュレーションについては, 少な いながらいくつかの事例が報告されており，Wen らは，拘 束緩和式 U 型高温割れ試験時の板表面の高温ひずみ履歴を 算出し，試験条件が高温ひずみに及ぼす影響について検討 している ${ }^{14)}$ 。また，Heらはレーザ溶接時の溶接高温割れに ついて, 溶接部に発生する応力を用いて解析的に評価して いる ${ }^{15)}$ ．また著者らの研究グループも，有限要素法 (Finite Element Method: FEM) を用いた解析により, 高温脆性温度域 (Brittleness Temperature Range: BTR) 内における塑性ひずみの 増分を割れ発生指標とする溶接高温割れ解析手法を提案し, 実大構造物の溶接に適用している ${ }^{16)}$ 。これらは，溶接に伴う 溶接部材の応力・ひずみを対象とした解析事例であるが, 溶融部の凝固に伴うひずみが考慮されていないため, 溶込 み形状や結晶成長に伴う溶接部のひずみを詳細に解析する のは困難であると考えられる

そこで著者らは，凝固収縮ひずみや凝固潜熱，結晶成長 方向などの凝固挙動と，溶接部に作用する高温ひずみを検 討可能な溶接高温割れ解析手法を開発し，シングルアーク による突合せ溶接に対して適用した ${ }^{17)}$ 。その結果，本手法を 用いることで，実験において発生した溶接部表面の溶接高 温割れを良好に再現することができ，溶接高温割れ発生を 予測可能であることを示した。また柱状晶どうしの会合位 置における会合角と高温ひずみの関係を明らかにし，会合 角が 180 度に近く，結晶どうしが平行に会合する位置にお いては，板幅方向の温度勾配が大きい，すなわち剛性が回 復した固相の領域から固液共存領域までの距離が小さく拘 束が大きいことから, 凝固収縮ひずみの影響を大きく受け, 割れが生じやすくなると結論づけた。それとは逆に，会合 角が 180 度から大きく変化する位置においては，凝固収縮 ひずみの発生する領域が小さくなることで, 凝固収縮ひず みの影響が小さくなるため割れが生じにくいと考えられる. 以上のことから，溶接部の温度勾配を制御し，溶接金属部 全域における柱状晶どうしの会合角を変化させることで, 溶接高温割れの発生を防止することができ, 生産性の向上 につながると考える.

本研究では, Fig. 1 に示す上述のシングルアーク溶接時に 生じた溶接金属表面部における溶接高温割れに対して, Fig. 2 に示すタンデム溶接における後行極を用いて溶接部の 凝固形態および温度勾配を制御することで，溶接高温割れ を防止する方法について検討を行う。すなわち，タンデム 溶接時の電極間距離 $\mathrm{L}_{\mathrm{Torch}}$ が, 柱状晶会合角および高温ひず

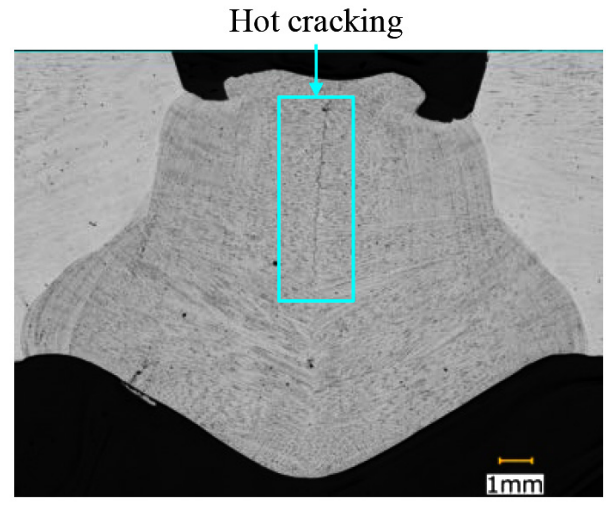

Fig. 1 Hot cracking in transverse cross section during single arc welding.

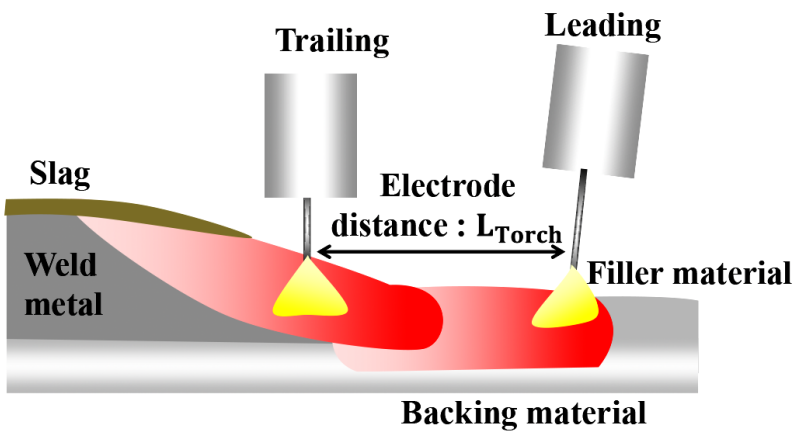

Fig. 2 Schematic illustration of tandem welding for preventing hot cracking.

みに及ぼす影響について溶接高温割れ解析を用いて検討し， 高温割れ防止条件を明らかにする。また実験結果との比較 から, タンデム溶接時における結晶成長方向および高温ひ ずみ予測についての妥当性を示すとともに，溶接高温割れ 防止条件の有効性についても検討する.

\section{2. 高温割れ解析手法}

本研究では，力学および治金学的因子を考慮した FEM 溶 接高温割れ解析 ${ }^{17)}$ を実施した。具体的には，固相率と温度 の関係を用いて, 固液の強度差, 凝固潜熱および凝固収縮 ひずみを考慮した。加えて，FEM 熱伝導解析を用いた柱状 晶成長方向の予測および FEM 熱弾塑性解析を用いた高温域 におけるひずみ評価を実施した。本章ではそれらの解析手 法の概略について述べる。

\section{1 材料定数の設定}

対象とする材料はJIS G 3106 SM490A とする．材料定数の 温度依存性は Fig. 3 に示す通りとした ${ }^{18)}$.

また，BTR内における凝固の進行を表現するために， Fig. 4 に示す BTR 内の温度と固相率の関係を用いて各要素に おける固相率を決定し ${ }^{17,19)}$ ，それに基づき溶接過渡期におけ る各要素の高温降伏応力, 凝固潜熱および凝固収縮を設定 


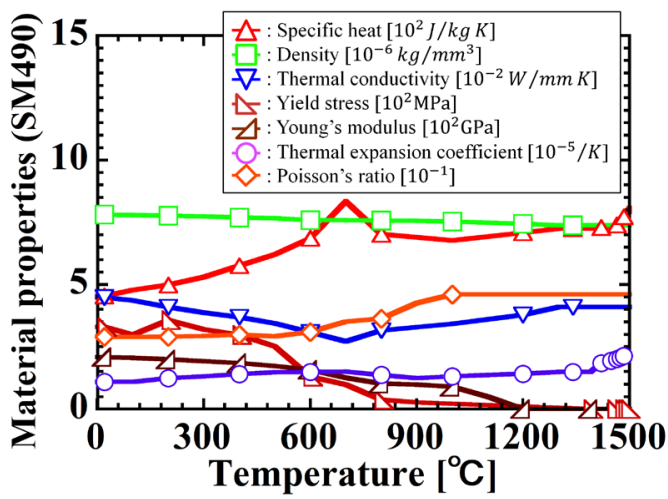

Fig. 3 Temperature dependent material properties of SM490A.

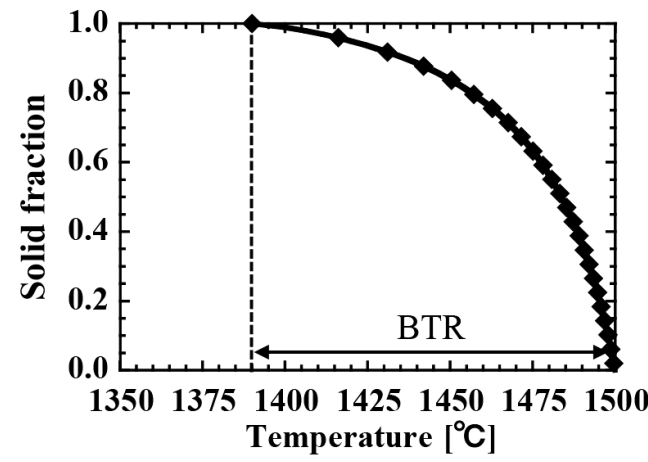

Fig. 4 Relation between temperature and fraction of solid.

した。なお，BTRは Fig. 4 で設定した凝固が開始する液相線 温度 $1500^{\circ} \mathrm{C}$ から凝固が完了する固相線温度 $1390^{\circ} \mathrm{C}$ までの $110^{\circ} \mathrm{C}$ とした ${ }^{17)}$.

固相線温度における高温降伏応力については炭素鋼の高 温引張試験時に計測された応力 ${ }^{20)}$ と同等の $1.0 \mathrm{MPa}$ とし, 液 相線温度以上では固相線温度と比べて十分に小さい $0.1 \mathrm{MPa}$ とした。 また，BTR内においては，固相率に比例した降伏 応力に設定することで, 固相と液相の強度差を考慮した. 同様に, 固相率の増加に伴い発生する凝固潜熱については, Fig. 4 に示す固相率と温度の関係に基づき高温域における比 熱を用いて表現した。すなわち本研究においては $270 \mathrm{~J} / \mathrm{g}^{21)}$ と仮定した，加えて，溶融金属の凝固時において，液体金 属と固体金属の密度差により生じる凝固収縮ひずみ $\varepsilon_{\mathrm{Sh}}$ を $3.0 \%{ }^{22,23)}$ とし，固相率に比例した凝固収縮ひずみを，線膨 張係数を用いて考慮した。

\subsection{BTR 塑性ひずみ増分}

溶接高温割れは, Fig. 5 に示すように, 凝固過程における BTRにおいて限界ひずみ以上の引張りひずみが生じた際に 発生すると考えられる ${ }^{3-8)}$ 。そこで本研究では，溶接高温割 れの発生を評価する指標として，塑性ひずみを採用する。 すなわち, Fig. 6 に示すような降温過程において，液相線温 度 $\mathrm{T}_{\mathrm{L}}$ に達した時点における塑性ひずみ值と, 固相線温度 $\mathrm{T}_{\mathrm{S}}$ に達した時点における塑性ひずみ值の差を, BTR 塑性ひず

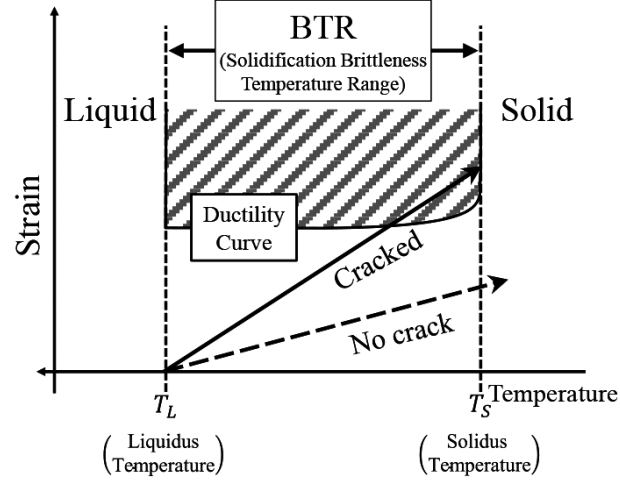

Fig. 5 Schematic illustration of occurrence of solidification cracking from a view point of relationship between ductility of alloy and deformation proposed by Matsuda ${ }^{6}$.

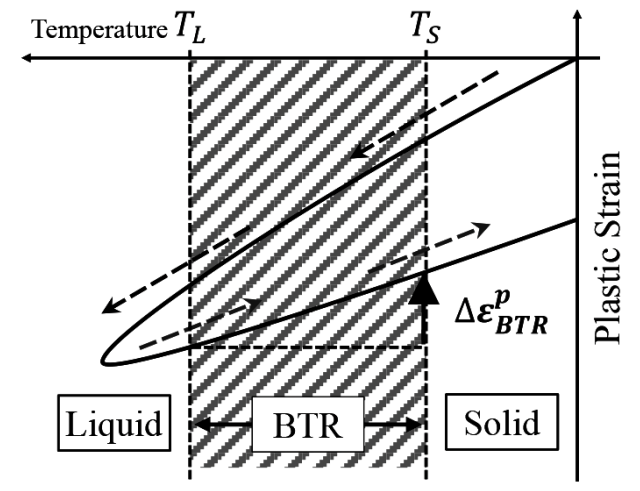

Fig. 6 Schematic illustration of plastic strain increment in BTR during cooling.

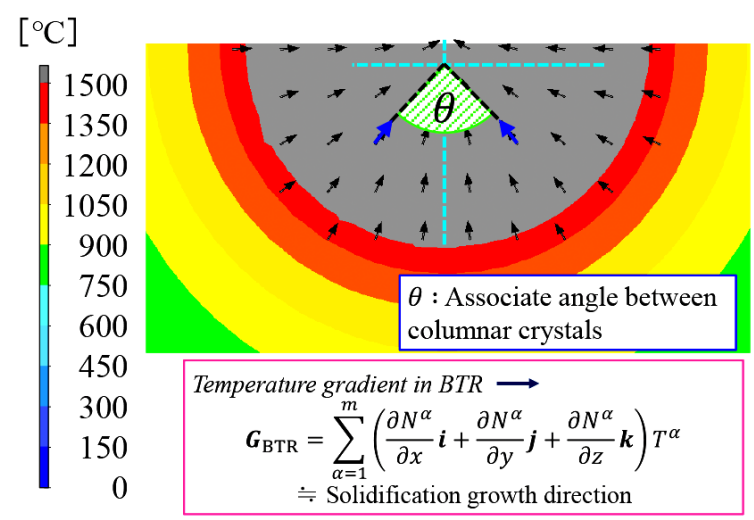

Fig. 7 Temperature gradient vector in BTR for columnar crystals growth direction and associate angle.

み増分と定義して, FEM 熱弾塑性解析により算出する.

\section{3 柱状晶成長方向簡易評価手法}

本研究では, 溶融池内の柱状晶の成長方向を, 各要素が 冷却中にBTRに達した時点における最大温度勾配の方向と 仮定し，これを BTR 温度勾配べクトル $G_{B T R}$ と定義する ${ }^{17)}$. これを，Fig.7に示すような会合位置に向かう凝固成長の角 度と併せて，FEM 熱伝導解析を用いて算出する。なお，図 
中の式内の $N^{\alpha}$ は FEMにおける形状関数であり, $m$ は一要 素あたりの節点数, $\boldsymbol{i}, \boldsymbol{j}, \boldsymbol{k}$ は各方向の基底べクトル， $T^{\alpha}$ は各 要素が降温過程において BTRに達した時点における各節点 の温度を示している。柱状晶どうしの会合部全域において 柱状晶の会合角度を実験結果と比較するため，溶接横断面 内の温度勾配を用いて会合角度を算出する。ここで，高温 割れの発生には，溶接線方向の温度勾配も影響すると考え られるが, 本研究では, 溶接金属内部の溶接線方向の柱状 晶の成長方向の取得が困難であったことに加え, 溶接速度 を一定とした検討を行うため, 溶接横断面内の温度勾配の みを用いた。 また，複数電極による入熱により再加熱され， 液相線温度を再度超えた要素についてはBTR 温度勾配べク トルを再計算し，再冷却中にBTRに達した時点における最 大温度勾配を基に BTR 温度勾配べクトル $G_{B T R}$ を新たに算出 する。 なお, BTR 温度勾配べクトル $G_{B T R}$ は, 単位ベクトル を用いてその方向を表示する，本手法は柱状晶の核となる 母材の組織形態や優先成長方向の異方性等を無視した簡易 評価手法であるが，本研究ではこの手法により得られたお およその柱状晶成長方向と割れ発生位置との関係について 検討する.

\section{3. タンデム溶接時の電極間距離が溶接高温割れ発生に及ぼ す影響}

シングル溶接時には，溶接金属の表面部において，溶接 高温割れが発生する場合があり問題となっている ${ }^{17)}$. 本章で は, 同様の突合せ溶接において, Fig. 2 に示したタンデム溶 接を用いて，溶接高温割れを防止可能な溶接条件について 検討を行う。すなわち先行電極によりビード表面部に生じ た溶接高温割れを再溶融しながら, 後行極の入熱によって
割れが生じにくい凝固組織を形成することが目的である. すなわちここでは，提案手法による解析結果と実試験の割 れ発生位置から, 本手法の有効性と割れ防止条件について 検討を行う。

\section{1 タンデム溶接による溶接高温割れ試験}

本節では，本研究で実施したタンデム溶接による溶接高 温割れ試験の詳細を示す。供試鋼板として JIS G 3106 SM490A を用いて, タンデム GMAWによる下向片面溶接を 行った，溶接ワイヤとして，先行電極に $\phi 1.6 \mathrm{~mm}$ の JIS Z 3313 T49J 0 T5-1 C A-U を用い, 後行電極に $\phi 1.4$ mm の JIS Z 3313 T49 2 T15-0 C A-G-Uを用いた. 先行電極の極性を DCEP とし，後行電極の極性をDCEN とすることによりアー ク干渉を抑制した。また開先内には溶融池の安定化と高溶 着化のために申 $1.2 \mathrm{~mm} \times 1.4 \mathrm{~mm}$ の開先充填剂を散布した. その際に用いた試験片の形状および寸法と実験結果につい て述べる. Fig. 8(a) に試験片の外観写真を示し, 同図 (b)に 試験片の寸法を示す。実験においては，同図 (a)(i)に示すよ うに溶接線の前後にタブ板を有する 2 枚の鋼板を突合せ溶接 により接合する。2 枚の鋼板の寸法は同図 (b)(i) に示すよう に, 長さ $900 \mathrm{~mm}$, 半幅 $150 \mathrm{~mm}$, 板厚 $25 \mathrm{~mm}$ である. また タブ板の寸法は, 長さ $150 \mathrm{~mm}$, 半幅 $150 \mathrm{~mm}$, 板厚 $25 \mathrm{~mm}$ である。なお，同図 (b)(i) に示すように $x$ 軸を定義する， $x$ $=125 \mathrm{~mm}, 425 \mathrm{~mm}$ および $725 \mathrm{~mm}$ の位置には, 長さ $50 \mathrm{~mm}$, 厚さ $5 \mathrm{~mm}$ の仮付け溶接を施工した。 また同図 (a)(ii)に示す ように母材の裏面部に拘束板を 3 枚設置し, 拘束板の形状は, 同図 (a)(iii)に示すようにU字型とし，それらを同図(b)(ii) に示すように, $x=200 \mathrm{~mm}, 440 \mathrm{~mm}$ および $680 \mathrm{~mm}$ の位置 に取り付けた。拘束板は, Fig. 8(a)(iii),(b)(iii)に示す通り,

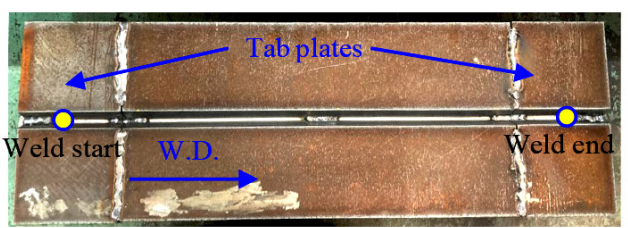

(i) Plan view.

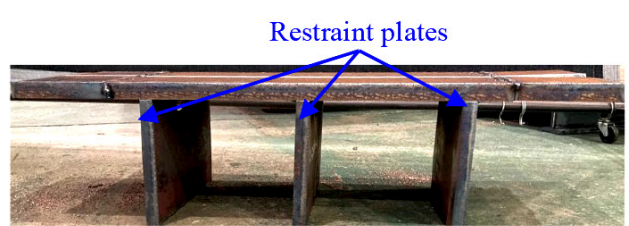

(ii) Side view.

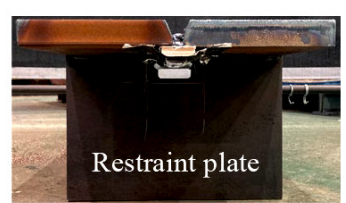

(iii) Front view.

(a) Photos of test specimen.

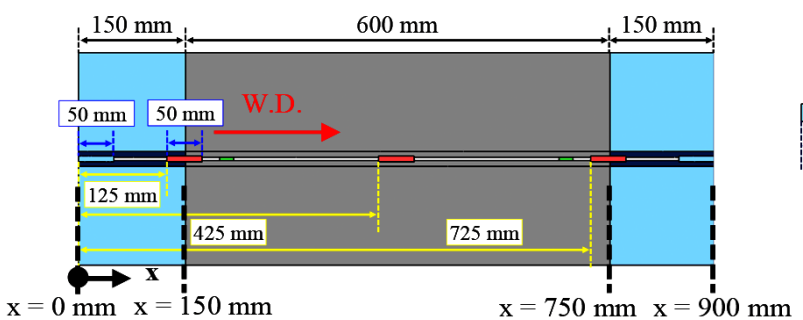

(i) Plan view.

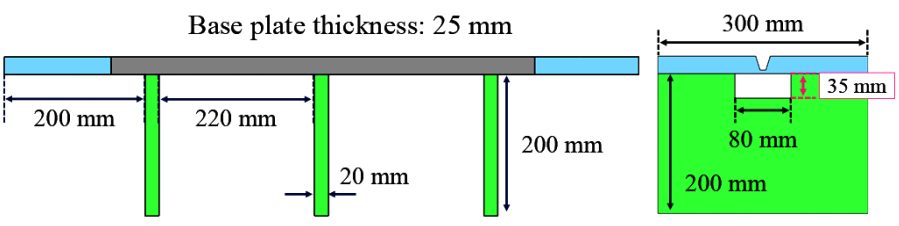

(ii) Side view.

(iii) Front view

(b) Shape and size of test specimen.

Fig. 8 Detail of test specimen with butt joint for tandem welding. 
幅 $300 \mathrm{~mm}$, 高さ $200 \mathrm{~mm}$, 厚さ $20 \mathrm{~mm}$ である. 溶接開始位 置は $x=50 \mathrm{~mm}$, 溶接終了位置は $x=850 \mathrm{~mm}$, すなわち溶接 長は $800 \mathrm{~mm}$ である. 先行電極の溶接電流, 溶接電圧および 溶接速度を，それぞれ $410 \mathrm{~A}, 32 \mathrm{~V}$ および $4.17 \mathrm{~mm} / \mathrm{s}$ とした。 また, 後行電極の溶接電流, 溶接電圧および溶接速度を, それぞれ $240 \mathrm{~A}, 24 \mathrm{~V}$ および $4.17 \mathrm{~mm} / \mathrm{s}$ とした。 なお，電極 間距離 $\mathrm{L}_{\mathrm{Torch}}$ を $30 \mathrm{~mm}$ とした。

Fig. 9 に実験においてX線透過試験で得られた溶接中心線 縦断面における割れ発生位置を示す。同図より，仮付けに 対して $x$ 軸における負の方向, すなわち仮付け位置後方の広 い範囲において割れが発生していることが確認できる．Fig. 10 に割れが確認された $x=340 \mathrm{~mm}$ における溶込み形状およ び断面マクロを示す。同図より溶接金属中央部において割 れが生じていることがわかる。また柱状晶どうしの会合部 全域において柱状晶の会合角度 (以下, 柱状晶会合角と称す) が 180 度に近く, 特に溶接金属中央部から表面部にかけて, 柱状晶どうしが真横に会合していることから, 割れが生じ やすい凝固形態であることが分かる.

\section{2 タンデム溶接時の溶接高温割れ解析の妥当性検証}

本節では，電極間距離 $\mathrm{L}_{\mathrm{T} o r c h}$ を $30 \mathrm{~mm}$ とした条件に対し 提案手法 ${ }^{17)}$ を適用し，柱状晶成長方向簡易評価および割れ
発生評価 ${ }^{17)}$ について妥当性検証を行う。解析においては, 溶接線 $800 \mathrm{~mm}$ の要素分割を 800 分割とし, 板幅方向には溶 接部ほど細かい不等分割を採用した。節点数および要素数 はそれぞれ 1,122,416 および 1,059,664である．先行電極の溶 接電流，溶接電圧および溶接速度を，それぞれ $410 \mathrm{~A}, 32 \mathrm{~V}$ および $4.17 \mathrm{~mm} / \mathrm{s}$ とし, 後行電極の溶接電流, 溶接電圧およ び溶接速度を,それぞれ $240 \mathrm{~A}, 24 \mathrm{~V}$ および $4.17 \mathrm{~mm} / \mathrm{s}$ とした。 熱効率は，実験および解析結果の温度履歴の比較から 0.6 と 設定した. Fig. 11 に示す全 6 点における実験および解析結果 の温度履歴を Fig. 12 に示す。同図より，実験結果と解析結 果が良好に一致していることが確認でき，溶接熱効率を 0.6 と設定したことが妥当であることが確認できる．熱効率を 0.6 とした場合, 先行電極の単位長さあたりの入熱量は 1880 $\mathrm{J} / \mathrm{mm}$ であり, 後行電極の単位長さあたりの入熱量は $828 \mathrm{~J} /$ $\mathrm{mm}$ である.

熱伝導解析においては，トーチの移動方向を長手方向と する領域内に存在する要素を一様に加熱するような体積発 熱モデルを用いた．先行電極および後行電極のそれぞれの 溶接金属部の形状は，実験結果の断面マクロを基に作成し， 実験結果の溶込み形状を再現できるように，入熱領域を決 定した。また溶接開始時には，先行電極および後行電極の 溶着金属に該当する要素は無効化された状態とし，溶接中

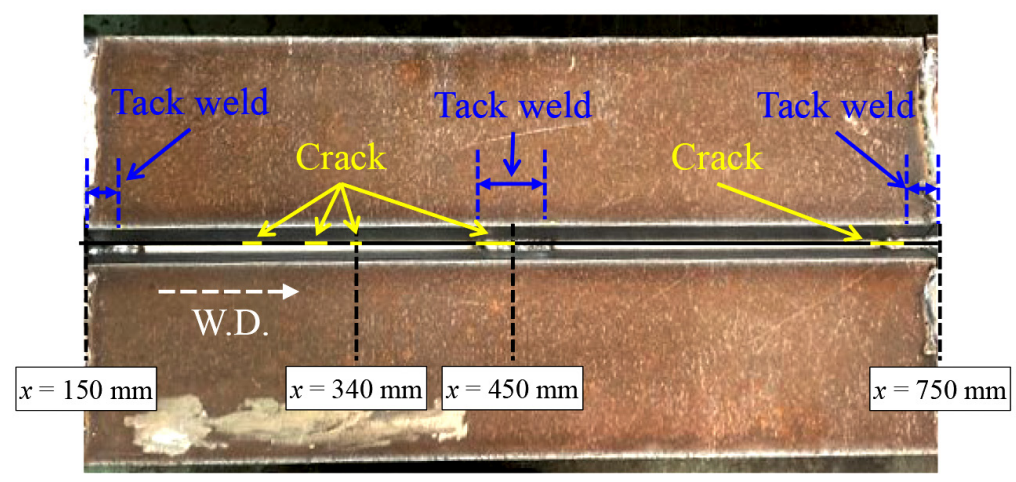

Fig.9 Cracked area in longitudinal section obtained by experiment when electrode distance $\mathrm{L}_{\text {Torch }}$ is $30 \mathrm{~mm}$.

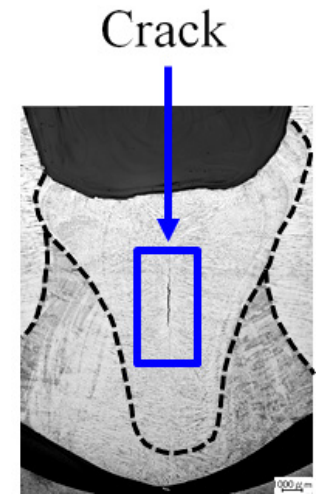

Fig. 10 Shape of weld metal with hot cracking with $\mathrm{L}_{\text {Torch }}=30 \mathrm{~mm}$ on transverse cross section at $\mathrm{x}=340 \mathrm{~mm}$

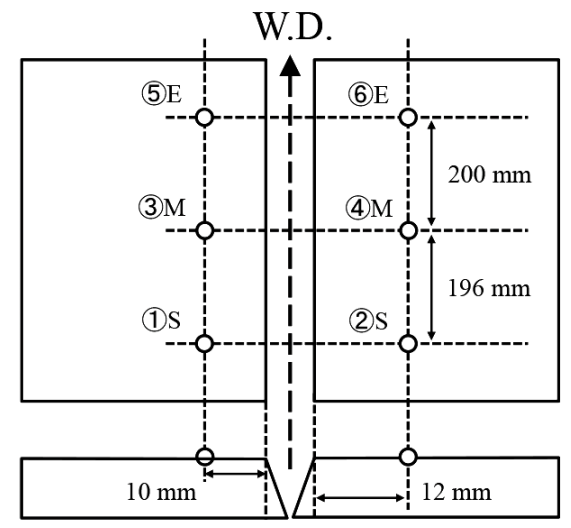

Fig. 11 Measurement points of temperature 
にトーチが到達した時点で, その要素を有効化するエレメ ントバース法 ${ }^{16)}$ を採用した。 また本研究では，デンドライ 卜の先端が会合する位置で生じる割れを解析対象とし，降 温過程の BTRにおける板幅方向の塑性ひずみの増分值を用 いて割れを評価した。

Fig. 13 に熱伝導解析から得られる BTR 温度勾配ベクトル を含む最高到達温度分布を示す。同図より，溶込み形状が

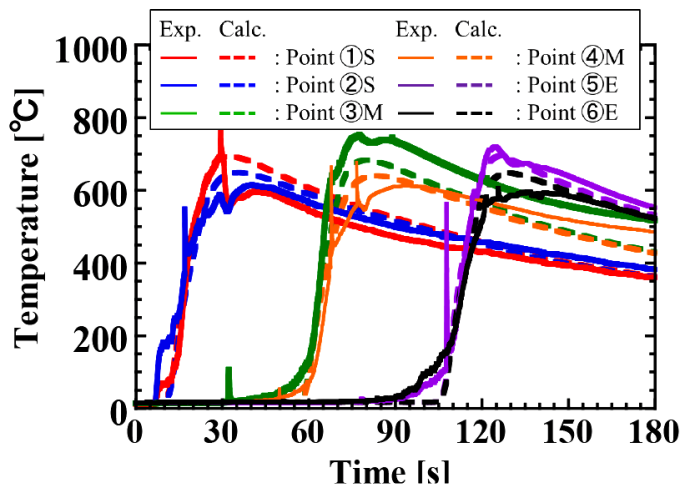

Fig. 12 Comparison of temperature history between analysis and experimental results.

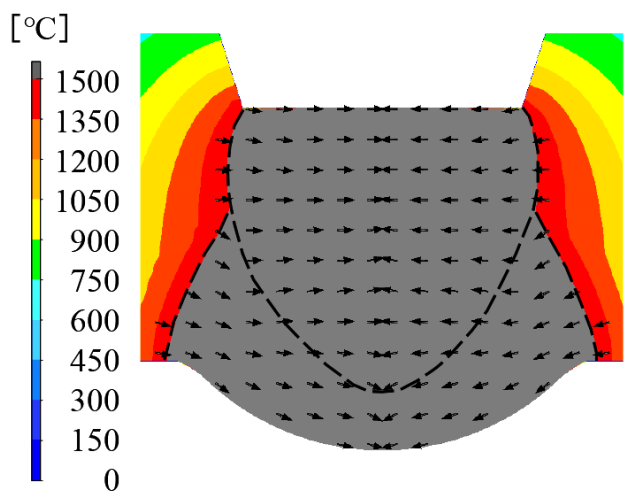

Fig. 13 Computed penetration shape and temperature gradient vector in $\mathrm{BTR}$ for $\mathrm{L}_{\mathrm{T} \text { orch }}=30 \mathrm{~mm}$ on transverse cross section at $x=$ $340 \mathrm{~mm}$.

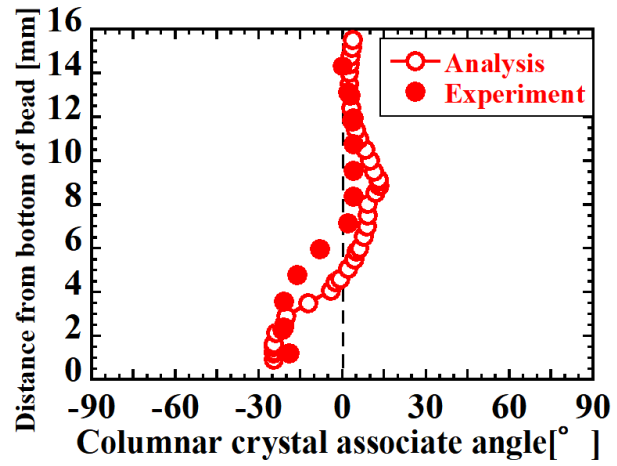

Fig. 14 Comparison of columnar crystals associate angle between analysis and experimental results for $\mathrm{L}_{\text {Torch }}=30 \mathrm{~mm}$ at $x=$ $340 \mathrm{~mm}$.
Fig. 10 に示した溶込み形状と良好に一致することが確認で きる.

次に柱状晶どうしの会合位置である溶接中心線を板厚方 向に 14 分割し，BTR 温度勾配ベクトルから算出した柱状晶 会合角と，Fig. 10 に示す実験における断面マクロ写真から 得られた柱状晶会合角を比較し Fig. 14 に示す。同図の縦軸 は溶接金属裏面からの距離を示し，横軸は柱状晶会合角の 大きさを示す。また図中の○印は解析結果を示し，○印は 実験結果を示す。同図より，図中○印で示す実験結果の凝 固成長方向および○印で示す解析結果の BTR 温度勾配べク トルがおおよそ一致していることから，タンデム溶接にお いても BTR 温度勾配べクトルを用いた柱状晶成長方向簡易 評価手法はある程度の精度で柱状晶の成長方向を評価可能 であることが確認できた。

さらに, Fig. 10 で示した断面マクロ写真と同じ, $x=340$ $\mathrm{mm}$ の横断面における解析結果として得られた BTR 塑性ひ ずみ増分の分布を Fig. 15 に示す. Fig. 10 より，実験では溶 接線中心線上において溶接高温割れが発生していることが 確認でき，Fig. 15 に示す解析結果においても，実験と同様 の位置において大きな引張りの BTR 塑性ひずみ増分が発生 していることが分かる。このことより，BTR塑性ひずみ増 分を評価指標とした FEM 熱弾塑性解析による溶接高温割れ 評価を用いることで，溶接横断面内に発生する溶接高温割

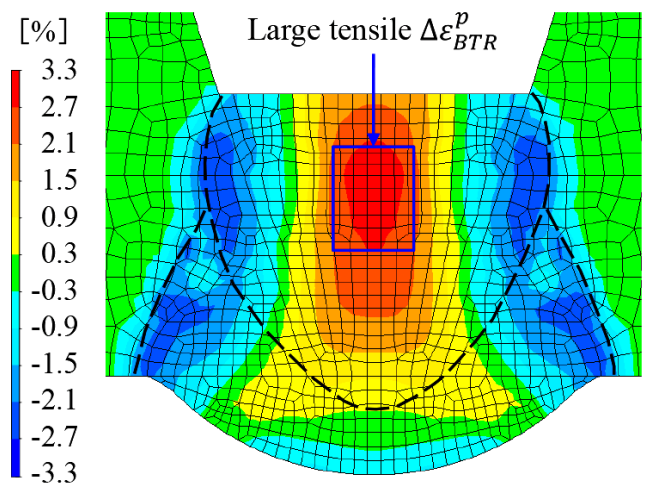

Fig. 15 Distribution of plastic strain increment in BTR obtained by computation for $\mathrm{L}_{\text {Torch }}=30 \mathrm{~mm}$ on transverse cross section at $x=340 \mathrm{~mm}$.

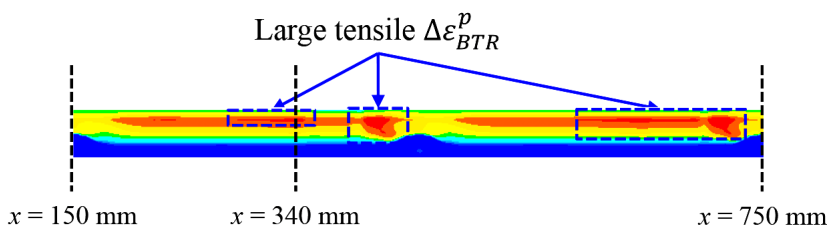

$\begin{array}{lllllllllll}3.30 & 3.03 & 2.76 & 2.49 & 2.22 & 1.95 & 1.68 & 1.41 & 1.14 & 0.87 & 0.60\end{array}$

[\%]

Fig. 16 Distribution of plastic strain increment in BTR obtained by computation and cracked area obtained by experiment for $\mathrm{L}_{\text {Torch }}=30 \mathrm{~mm}$. 
れ発生の可能性の高い領域を推定可能であると言える. 次 に, Fig. 16 に電極間距離 $\mathrm{L}_{\text {Torch }}$ を $30 \mathrm{~mm}$ とした場合の解析に おける溶接中心線縦断面内の BTR 塑性ひずみ増分の分布を 示す。なお，実験結果の割れ発生位置との比較のために図 のコンターレンジを調整している，同図より，仮付け位置 後方の広い範囲において高い BTR 塑性ひずみ増分が分布し ていることが確認できる。 また，同図で得られた高いひず み位置と同様の位置において, Fig.9の実験結果より割れが 発生していることが確認できる。これらの結果より, 本手 法を用いることで，溶接中心線縦断面内に発生する溶接高 温割れについても割れ発生の可能性の高い領域を推定可能 であると考えられる.

\section{4. タンデム溶接時の割れ防止条件に関する検討}

\section{1 電極間距離 $\mathrm{L}_{\mathrm{Torch}}$ が柱状晶成長方向および BTR 塑性 ひずみ増分に及ぼす影響}

3.2 節の検討により，会合角度が 180 度に近く，高い BTR 塑性ひずみ増分が発生している位置で割れが発生している ことが示されたことから, 会合角度を変化させる, もしく はBTR 塑性ひずみ増分を低減することで，割れを防止する ことが出来ると考えられる。本節では，タンデム溶接にお ける後行極を用いて溶接部の凝固形態および温度勾配を制 御し，溶接高温割れを防止する条件について検討を行う。 入熱量および溶接速度は， 3.2 節に示す通り，先行電極およ び後行電極の入熱量をそれぞれ $1889.3 \mathrm{~J} / \mathrm{mm}$ および $829.4 \mathrm{~J} /$ $\mathrm{mm}$ とし，溶接速度を $4.17 \mathrm{~mm} / \mathrm{s}$ とした。これらの条件下に おいて，電極間距離 $\mathrm{L}_{\mathrm{T} \text { orch }}$ を $10 \mathrm{~mm} \sim 150 \mathrm{~mm}$ まで $20 \mathrm{~mm}$ 間 隔で変化させ，電極間距離 LTorch が溶接高温割れ発生に及
ぼす影響について検討した，実試験では電極間距離が変化 すると後行電極により形成される溶接金属部の形状が変化 するが，本解析においては，すべての電極間距離 $\mathrm{L}_{\mathrm{T} \text { orch }}$ の条 件において，前節で用いた入熱領域を使用した。

Fig. 17 に，電極間距離 $\mathrm{L}_{\text {Torch }}$ が $10 \mathrm{~mm}, 30 \mathrm{~mm}, 50 \mathrm{~mm}, 70$ $\mathrm{mm}$ および $130 \mathrm{~mm}$ の場合の溶接中心線縦断面内における溶 接過渡の温度分布を示す。同図 (a), (b) より電極間距離 $\mathrm{L}_{\mathrm{T} \text { orch }}$ が $30 \mathrm{~mm}$ 以下の条件においては，溶融領域（ $1500^{\circ} \mathrm{C}$ 以上） が結合し 1 つになているのに対して, 同図(c), (d), (e) に示 す電極間距離 $\mathrm{L}_{\text {Torch }}=50 \mathrm{~mm}$ 以上の条件では溶融領域が前後 に2つ存在することが確認できる.

Fig. 18 に, FEM 熱伝導解析により得られる BTR 温度勾配 ベクトルを含む最高到達温度分布を示す。同図 (a), (b)に示 す電極間距離が比較的小さい $\mathrm{L}_{\text {Torch }}=10 \mathrm{~mm}, 30 \mathrm{~mm}$ の条件 においては溶接金属表面部の柱状晶会合角が 180 度に近く 割れが生じやすい凝固形態となっていることが確認でき, 同図 (c) に示す $\mathrm{L}_{\mathrm{Torch}}=50 \mathrm{~mm}$ の条件においては, 後行電極の 影響により溶接金属表面部の柱状晶会合角が改善されてい ることが分かる．同図 (d), (e) に示す電極間距離が比較的大 きい $\mathrm{L}_{\text {Torch }}=70 \mathrm{~mm}, 130 \mathrm{~mm}$ の条件においては, 後行電極の 影響により柱状晶会合角が 180 度より小さくなっており，割 れが生じにくい凝固形態であることが確認できる。また， 電極間距離 $\mathrm{L}_{\text {Torch }}$ が大きくなるほど後行電極により溶融され た領域が小さくなっていることが分かる．Fig. 19 に， $x=340$ $\mathrm{mm}$ の横断面における BTR 塑性ひずみ増分の分布を示す. 同図 (a), (b), (c) に示す電極間距離 $\mathrm{L}_{\mathrm{Torch}}$ が比較的小さい条件 では，後行電極による溶接金属内部における BTR 塑性ひず み増分が大きくなっており, 同図 (d), (e) に示す電極間距離 $\mathrm{L}_{\text {Torch }}$ が比較的大きな $70 \mathrm{~mm}$ および $130 \mathrm{~mm}$ の条件において

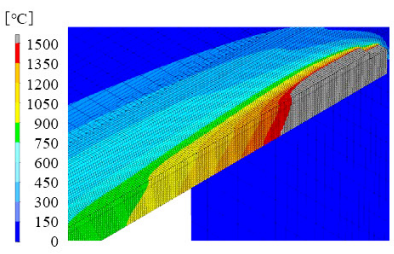

(a) $\mathrm{L}_{\text {Torch }}=10 \mathrm{~mm}$

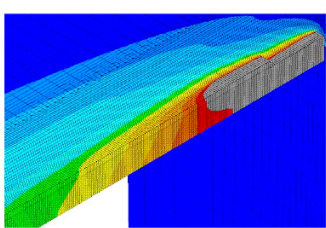

(b) $\mathrm{L}_{\text {Torch }}=30 \mathrm{~mm}$

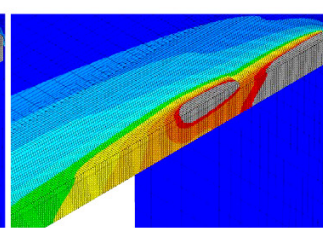

(c) $\mathrm{L}_{\text {Torch }}=50 \mathrm{~mm}$

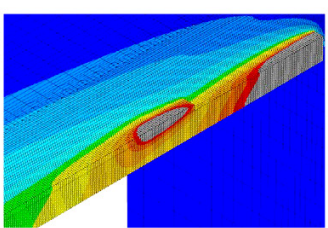

(d) $\mathrm{L}_{\text {Torch }}=70 \mathrm{~mm}$

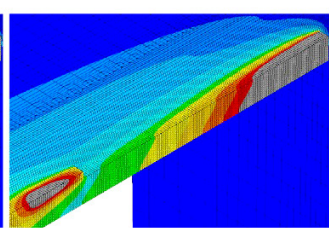

(e) $\mathrm{L}_{\text {Torch }}=130 \mathrm{~mm}$

Fig. 17 Temperature distribution for each electrode distance $\mathrm{L}_{\text {Torch }}$ during welding.

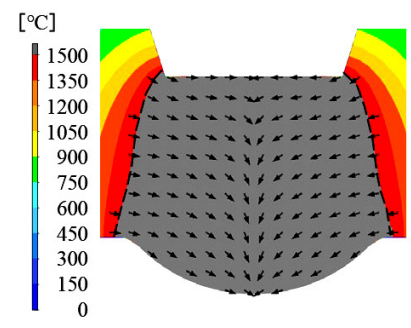

(a) $\mathrm{L}_{\text {Torch }}=10 \mathrm{~mm}$

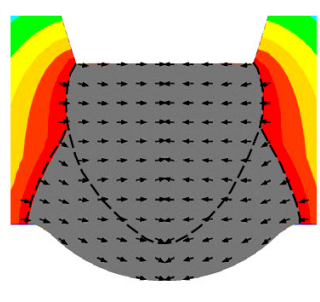

(b) $\mathrm{L}_{\text {Torch }}=30 \mathrm{~mm}$

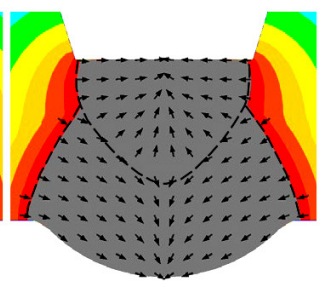

(c) $\mathrm{L}_{\text {Torch }}=50 \mathrm{~mm}$

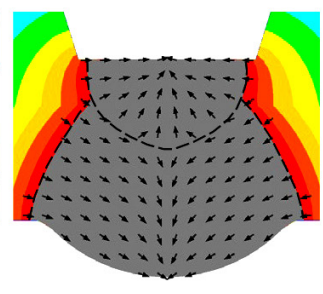

(d) $\mathrm{L}_{\text {Torch }}=70 \mathrm{~mm}$

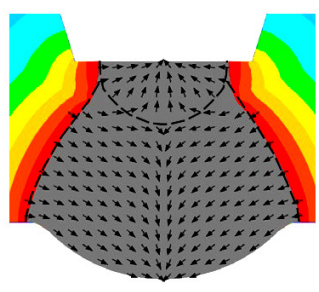

(e) $\mathrm{L}_{\text {Torch }}=130 \mathrm{~mm}$

Fig. 18 Computed penetration shape and temperature gradient vector in BTR for each electrode distance $\mathrm{L}_{\text {Torch. }}(x=340 \mathrm{~mm})$ 
は，その領域のひずみ量は小さくなっていることが分かる.

Fig. 20 に，図中に示す A-A'線上における BTR 塑性ひずみ 増分分布を示す．同図の縦軸は，溶接金属裏面からの距離 を示し，横軸はBTR 塑性ひずみ増分を示している。また図

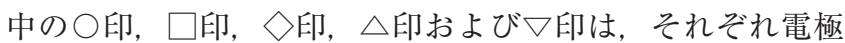
間距離 $\mathrm{L}_{\text {Torch }}$ が $10 \mathrm{~mm}, 30 \mathrm{~mm}, 50 \mathrm{~mm}, 70 \mathrm{~mm}$ および $130 \mathrm{~mm}$ の結果を示している。同図より, 溶接金属裏面からの距離 が $11 \mathrm{~mm}$ 程度の溶接金属表面部付近においては, 電極間距 離 $\mathrm{L}_{\mathrm{T} \text { orch }}$ が小さいほど BTR 塑性ひずみ増分が大きく，電極間 距離 $\mathrm{L}_{\mathrm{T} \text { orch }}$ が最小である $10 \mathrm{~mm}$ の条件において最大 $3.2 \%$ 以 上の大きな BTR 塑性ひずみ増分が発生している。一方，電 極間距離が比較的大きな $\mathrm{L}_{\mathrm{T} \text { orch }}=70 \mathrm{~mm}, 130 \mathrm{~mm}$ の場合にお いては，BTR塑性ひずみ増分の最大值が比較的小さく抑え られていることが確認できる。このことから，溶接金属表 面部付近における割れを防止するためには，電極間距離 $\mathrm{L}_{\mathrm{Torch}}$ が大きい条件を用いることが適切であると考えられる. しかしながら, 裏面から $9 \mathrm{~mm}$ 程度の溶接金属中央部におけ る BTR 塑性ひずみ増分について, 電極間距離 $\mathrm{L}_{\mathrm{T} \text { orch }}$ が比較的 大きい $70 \mathrm{~mm}$ および $130 \mathrm{~mm}$ の結果を比較すると，電極間 距離 $\mathrm{L}_{\mathrm{T} \text { orch }}$ が大きい $130 \mathrm{~mm}$ の条件の方がひずみ量が大きく なっていることが分かる．これは，電極間距離 $\mathrm{L}_{\text {Torch }}$ が大き い場合，先行電極によって置かれた溶接ビードの冷却が進 むことにより，後行電極到達時における熱の重畳が小さく なり，後行電極により溶融された領域が縮小するためであ
ると考えられる。

Fig. 21 に電極間距離 $\mathrm{L}_{\text {Torch }}$ と $x=340 \mathrm{~mm}$ の断面における BTR 塑性ひずみ増分の最大值との関係を示す。同図の縦軸 は，BTR 塑性ひずみ増分の最大值を示し，横軸は電極間距 離 $\mathrm{L}_{\text {Torch }}$ を示している. 同図より, 電極間距離 $\mathrm{L}_{\text {Torch }}$ が比較的 小さい条件では $3.0 \%$ 以上の大きな BTR 塑性ひずみ増分が 発生している。また電極間距離 $\mathrm{L}_{\text {Torch }}$ が比較的大きい $90 \mathrm{~mm}$ 以上では，電極間距離 $\mathrm{L}_{\mathrm{T} \text { orch }}$ が大きいほど後行電極により溶 融される領域が小さくなるために, BTR 塑性ひずみ増分の 最大值がわずかに増加していることが確認できる．以上よ り, 電極間距離 $\mathrm{L}_{\text {Torch }}: 70 \mathrm{~mm} \sim 90 \mathrm{~mm}$ 程度の条件を用いる ことで, 本試験体の拘束条件においては溶接高温割れを低 減することができると考えられる。

\section{2 割れ防止条件の検証}

本節では, 4.1 節で示した割れ防止条件 $\mathrm{L}_{\mathrm{Torch}}$ : 70 90 mm の有効性についての検証することを目的として，電極間距 離 $\mathrm{L}_{\mathrm{T} \text { orch }}$ が $80 \mathrm{~mm}$ の条件において解析を行った。溶接条件と しては，3.2節に示す通り，先行電極および後行電極の入熱 量をそれぞれ $1880 \mathrm{~J} / \mathrm{mm}$ および $828 \mathrm{~J} / \mathrm{mm}$ とし，溶接速度は $4.17 \mathrm{~mm} / \mathrm{s}$ とした。 また実験結果と溶込み形状を合わせるた めに入熱領域を調整した. Fig. 22 に電極間距離 $\mathrm{L}_{\text {Torch }}$ を 80 $\mathrm{mm}$ とした解析での溶接中心線縦断面における BTR 塑性ひ ずみ増分の分布を示す。同図より，溶接線全域に亘り BTR

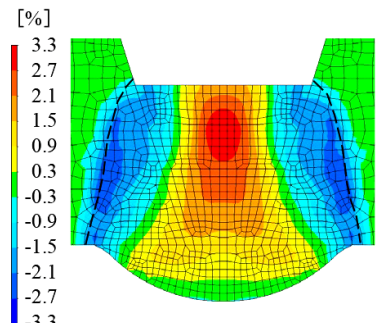

(a) $\mathrm{L}_{\text {Torch }}=10 \mathrm{~mm}$

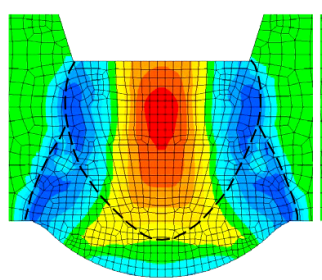

(b) $\mathrm{L}_{\text {Torch }}=30 \mathrm{~mm}$

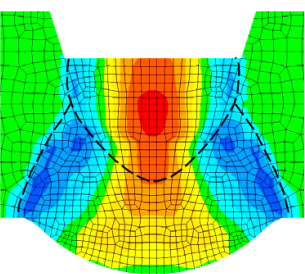

(c) $\mathrm{L}_{\text {Torch }}=50 \mathrm{~mm}$

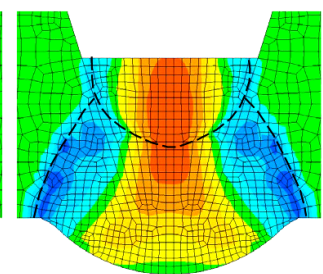

(d) $\mathrm{L}_{\text {Torch }}=70 \mathrm{~mm}$

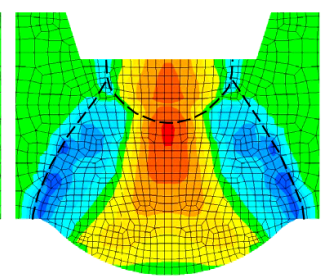

(e) $\mathrm{L}_{\text {Torch }}=130 \mathrm{~mm}$

Fig. 19 Distribution of plastic strain increment in BTR for each electrode distance $\mathrm{L}_{\text {Torch. }}(x=340 \mathrm{~mm})$

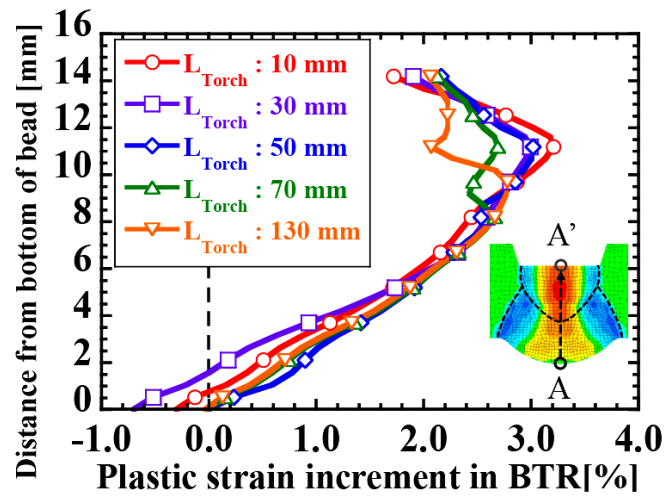

Fig. 20 Distribution of plastic strain increment in BTR for each electrode distance $\mathrm{L}_{\text {Torch. }}(x=340 \mathrm{~mm})$

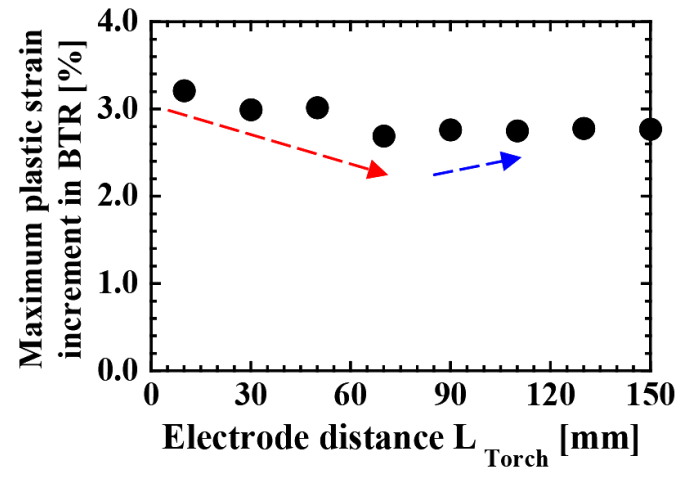

Fig. 21 Maximum plastic strain increment in BTR for each electrode distance $\mathrm{L}_{\text {Torch }}$ 


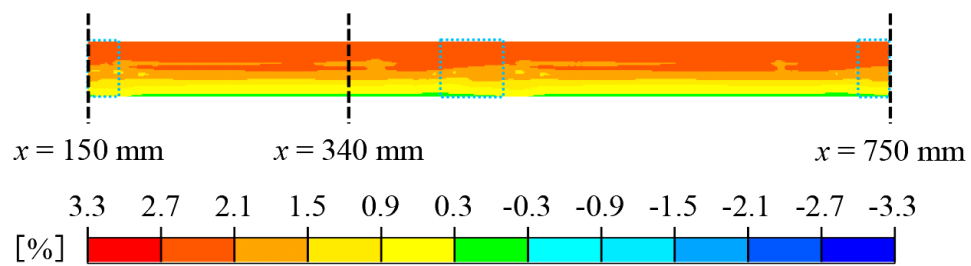

Fig. 22 Distribution of plastic strain increment in BTR in longitudinal section with $\mathrm{L}_{\text {Torch }}=80 \mathrm{~mm}$.
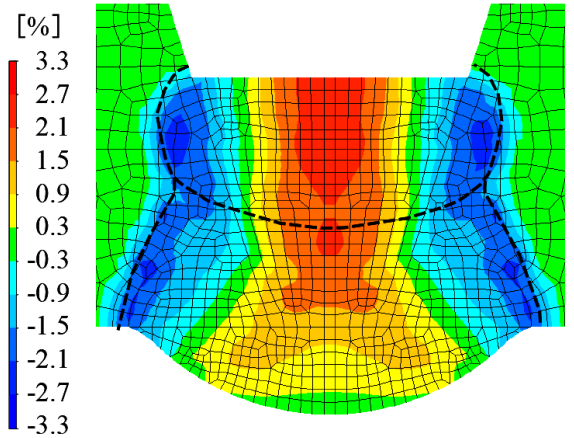

(a) Analysis result.

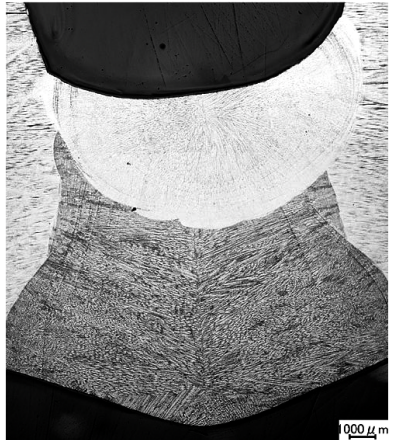

(b) Experimental result.

Fig. 23 Distribution of plastic strain increment in BTR obtained by computation and cross-sectional macrostructure obtained by experiment with $\mathrm{L}_{\text {Torch }}$ $=80 \mathrm{~mm}$ on transverse cross section at $x=340 \mathrm{~mm}$.

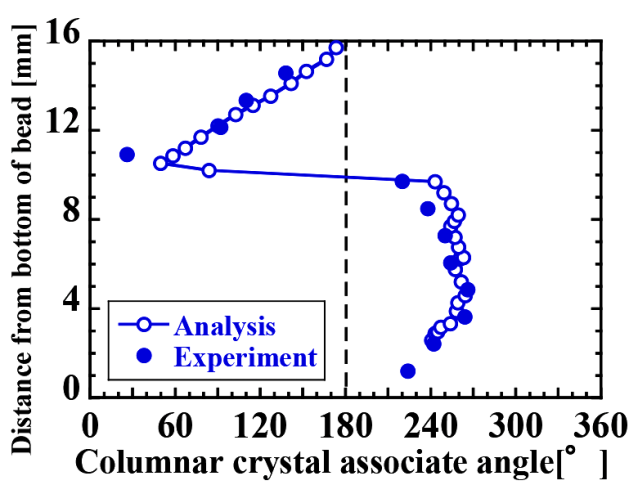

Fig. 24 Comparison of columnar crystals associate angle between analysis and experimental results with $\mathrm{L}_{\text {Torch }}=80 \mathrm{~mm}$ at $x=$ $340 \mathrm{~mm}$.

塑性ひずみ増分は $2.7 \%$ 以下と小さく抑えられていることが 分かる.

Fig. 23 (a)に, $x=340 \mathrm{~mm}$ の位置での溶接横断面内におけ る BTR 塑性ひずみ増分の分布を示す。また同図 (b)に実験 結果の $x=340 \mathrm{~mm}$ の位置における断面マクロ写真を示す. 同図 (a)より後行電極による溶接金属内部における BTR 塑性 ひずみ増分は小さく, Fig. 16 に示した電極間距離 $\mathrm{L}_{\text {Torch }}$ を 30 $\mathrm{mm}$ とした場合と比較して, 溶接高温割れ発生の可能性は小 さいと考えられる. また, 同図 (b) より溶接高温割れは発生 していないことが確認できる.さらに, 実験に用いた溶接 継手全長を対象としたX線透過試験においても割れが確認
されなかった。

Fig. 24 に電極間距離 $\mathrm{L}_{\text {Torch }}$ が $80 \mathrm{~mm}$ の条件において, 柱状 晶どうしの会合位置である溶接中心線を板厚方向に 14 分割 し, BTR 温度勾配べクトルから算出した柱状晶会合角と, Fig. 23 に示す実験における断面マクロ写真から得られた柱 状晶会合角の比較を示す。同図の縦軸は溶接金属裏面から の距離を示し，横軸は柱状晶会合角の大きさを示す。また 図中の○印は解析結果を示し，○印は実験結果を示す。同 図より, 図中○印で示す実験結果の凝固成長方向および○ 印で示す解析結果の BTR 温度勾配ベクトルがおおよそ一致 していることがわかり, 後行極の影響により, 溶接金属表 面部の柱状晶会合角が 180 度よりも小さくなっており, 割 れが生じにくい凝固形態であることが確認できる.

以上より, 本手法を用いることで, 溶接高温割れが発生 しない溶接条件を導出可能であることが分かった。また， 会合角度が 180 度より小さく, 高い BTR 塑性ひずみ増分が 発生する位置に生じていた溶接高温割れに対して, タンデ ム溶接を用いて溶接部の温度勾配を制御することで, 割れ が生じにくい会合角度を形成できることも分かった。ささら に, ひずみ量を低減することで, 割れが生じない溶接施工 が可能であることが示された.

\section{5. 結言}

本研究では，溶接高温割れを防止することを目的に，力 学および治金学的因子を考慮した FEM 溶接高温割れ解析手 
法を突合せ溶接に適用し，タンデム突合せ溶接時の電極間 距離が溶接高温割れ発生に及ぼす影響について検討した。 また解析結果および実験結果を比較した結果，以下の知見 が得られた。

1) 実験で得られた断面マクロ写真と BTR 温度勾配べクト ルを用いて決定された凝固成長方向の比較から，実験 結果と解析結果が良好に一致することが確認された。 このことから，タンデム溶接時においても BTR 温度勾 配ベクトルを用いることで簡易的にではあるが結晶成 長が予測可能であることが示された。

2)解析結果として得られた縦断面における BTR 塑性ひず み増分が大きい位置で, 溶接高温割れの発生が確認さ れた。このことにより，本手法を用いることで溶接高 温割れの発生の可能性の高い領域を推定可能と考えら れる。また，溶接高温割れは，横断面において会合角 度が 180 度に近い，すなわち柱状晶どうしが真横に会 合しており, 高いBTR 塑性ひずみ増分が発生している 位置で発生していることが確認された。

3) 電極間距離 $\mathrm{L}_{\mathrm{T} \text { orch }}$ が小さい場合においては，溶接金属中 央部から表面部にかけて柱状晶会合角が 180 度に近く なり，割れが生じやすい凝固形態になることが分かっ た. 一方，電極間距離 $\mathrm{L}_{\text {Torch }}$ が大きい場合においては, 溶接金属表面部での柱状晶会合角が 180 度より小さく なり，割れが生じにくい凝固形態になることが分かっ た.このことから, 電極間距離が比較的大きい条件に おいては, 割れが生じにくい凝固形態が形成されるこ とが確認された。

4) 電極間距離 $\mathrm{L}_{\mathrm{Torch}}$ が小さい場合においては，溶接金属表 面部で $3.0 \%$ 以上の高い引張りの BTR 塑性ひずみ増分 が生じており，電極間距離 $\mathrm{L}_{\mathrm{T} \text { orch }}$ が大きい場合において は, $2.7 \%$ 以下となることが確認された。このことから, 今回の溶接条件においては，電極間距離 $\mathrm{L}_{\mathrm{Torch}}$ が比較的 大きい条件を用いることで，溶接金属表面部における 割れを低減できる可能性が高いことが確認された。ま た電極間距離が比較的大きい $\mathrm{L}_{\mathrm{T} \text { orch }}=80 \mathrm{~mm}$ の実験にお いて溶接高温割れは発生せず，溶接高温割れ防止条件 の有効性が示された.

\section{参 考 文 献}

1) Y. Okumoto: Applications of Welding and Joining Technology (Shipbuilding), Journal of the Japan Welding Society, 79-6 (2010), 593-598. (in Japanese)

2) K. Hosoi and N. Hara: Cracking of Welded Joint, Journal of the Japan Welding Society, 78-6 (2009), 555-561. (in Japanese)

3) T. Senda, F. Matsuda, G. Takano, K. Watanabe, T. Kobayashi and T. Matsuzaka: Studies on Solidification Crack Susceptibility for Weld Metals with Trans-Varestraint test (1) -Investigation for Commercially Used Constructional Metals and Alloys-, Journal of Japan Welding Society, 41-6 (1972), 709-723. (in Japanese)

4) N. N. Prokhorov, The technical strength of metals while crystallizing during welding, Welding Production, 9-4 (1962), 1-8

5) W. S. Pellini, Strain Theory of Hot Tearing, Foundry, 80 (1952), 125 -
199.

6) F. Matsuda: Hot Cracking in Welded Joints of Steels, Sanyo Technical Report, 5-1 (1998), 8-19. (in Japanese)

7) P. WEN, K. SHINOZAKI, M. YAMAMOTO, Y. SENDA, T. TAMURA and N. NEMOTO: In-situ Observation of Solidification Cracking of Laser Dissimilar Welded Joints., Quarterly Journal of the Japan Welding Society, 27-2 (2010), 134s-138s

8) J. H. Lee, Y. Itasaka, S. Yamashita, T. Ogura, K. Saida: Prediction of solidification cracking during arc welding of $310 \mathrm{~S}$ stainless steel in U-type hot cracking test, Quarterly Journal of the Japan Welding Society, 38-2 (2020), 68-75.

9) T. Branza, F. Deschaux-Beaume, G. Sierra and P. Lours: Study and Prevention of cracking during weld-repair of heat-resistant cast steels., Journal of Materials Processing Technology, Elsevier, 209, (2009), 536-547.

10) J. H. Lee, S. Yamashita, T. Ogura and K. Saida: Solidification cracking prevention by thermal strain control via water-cooled gas tungsten arc welding., Materials Today Communications, 23, (2020), No.101109.

11) M. Schaefer, S. Kessler and P. Scheible: Modulation of the laser power to prevent hot cracking during laser welding of tempered steel., Journal of Laser Applications, 29 (2017), No.042008.

12) X. Zhang, Z. Cao and P. Zhao, Investigation on solidification cracks in pulsed laser spot welding of an AZ31 magnesium alloy., Optics \& Laser Technology, 126 (2020), No.106132.

13) S. Ohshita, N. Yurioka, N. Mori and T. Kimura: Prevention of Solidification Cracking in Very Low Carbon Steel Welds, WJ Research Supplements, (1983), 129s-136s.

14) P. Wen, K. Shinozaki, M. Yamamoto, Y. Senda, T. Tamura and N. Nemoto: Prediction of Solidification Cracking by In-situ Observation and 3D FEM-Analysis, Quarterly Journal of the Japan Welding Society, 27-2 (2009), 139s-143s.

15) Q. He, H. Wei, J. S. Chen, H. P. Wang and B. E. Carlson, Analysis of hot cracking during lap joint laser welding processes using the melting state-based thermomechanical modeling approach, International Journal of Advanced Manufacturing Technology, 94 (2018), 4373-4386.

16) T. Harada, K. Ikushima, M.Shibahara, F. Kimura and T. Morimoto Study on Solidification Cracking Under High-speed Narrow Gap Welding with Tandem Torches, Quarterly Journal of the Japan Welding Society, 33-2 (2015), 190s-194s.

17) S. Maeda, K. Ilushima, M. Shibahara, N. Ma: Development of Analysis Method for Hot Cracking Considering Mechanical and Metallurgical Factors, Quarterly Journal of the Japan Welding Society, 39-4 (2021), 386-395.

18) Project of Integrity Assessment of Flawed Components with Structural Discontinuity (IAF) Material Properties Data Book at High Temperature for dissimilar metal welding in Reactor Pressure Vessel, Japan Nuclear Energy Saftety Organization, 120-128. (in Japanese)

19) T. W. Clyne, M. Wolf and W. Kurz: The Effect of Melt Composition on Solidification Cracking of Steel, with Particular Reference to Continuous Casting, Metallurgical and Materials Transactions B, 13 (1982), 259-266.

20) H. Mizukami, S. Hiraki, M. Kawamoto, T. Watanabe: Tensile Strength of Carbon Steel during and after Solidification, Tetsu-toHagane, 84-11 (1998), 763-769. (in Japanese)

21) 機械工学便覧B-2-5, B-2-7, 日本機械学会.

22) P. J. Wray: Predicted Volume Change Behavior Accompanying the Solidification of Binary Alloys, Metallurgical Transactions B, 7 (1976), 639-646.

23) T. Yokoyama, Y. Ueshima, Y. Mizukami, H. Kakimi, M. Kato : Effect of $\mathrm{Cr}, \mathrm{P}$ and Ti on Density and Solidification Shrinkage of Iron, Tetsu-to-Hagane, 83-9 (1997), 557-562. (in Japanese) 